\title{
Should the laws on involuntary manslaughter in England and Wales be reformed? \\ Group 3
}

By L.Todd, K.Usman, F.Tyler, L.Toffolo, A.Temple

\section{Introduction}

The Group research focuses on the prevalent issues and the necessary reforms surrounding involuntary manslaughter. There was a general consensus in basing our research question upon the area of criminal law.

Whilst there are 3 distinct categories to involuntary manslaughter these being; Constructive, Gross Negligence, and Reckless manslaughter, the group decided to also provide a separate category for corporate manslaughter a section clearly under the umbrella of all 3 sections.

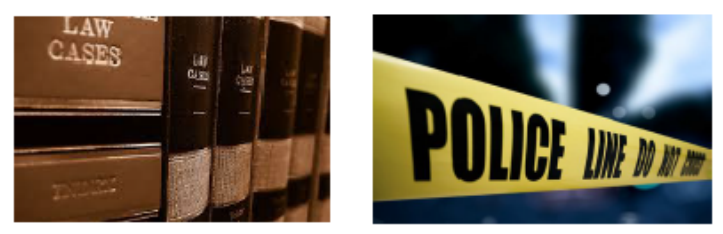

Research Findings

The law in this area is often ambiguous and therefore unpredictable.

Possible reforms include better sentencing/broader sentencing discretion and codification of the law.

BUT there may be resistance to reform due to the flexibility afforded by current offences.

\section{涌} University NEWCASTLE

\section{Results}

\section{Constructive Manslaughter}

The issues found within constructive manslaughter ix the lack of set statute offering definitions or legal principles. Having been developed through common law, leading to uncertainty of the law. An area that exemplifies this issue is the matter of 'one-punch killers', graphically illustrating the common objection that the defendant lacks sufficient moral culpability.

Gross negligence manslaughter

The lack of a clear and precise definition of the law on gross manslaughter has lead to issues within gross negligence manslaughter. The issues that prevail is the uncertainty and inconsistency that is as Adomako "offers very little guidance as to what is meant by the elusive principle of 'grossness'. Reckless manslaughter

There is an ongoing academic debate over the term 'reckless'. The Law Commission has stated that whilst 'reckless' causes confusion, they also state that 'there is no other word equally suitable to serve as a label". Whilst it allows flexibility within the common law, it removes the element of predictability within the law.

\section{Corporate manslaughter}

Corporate Manslaughter and Corporate Homicide Act 2007 creates two laws, the corporation is prosecuted under the Act, but managers or directors are still charged with the common law of gross negligence manslaughter which has a very high threshold. Creating two separate trials. If the organisation is found guilty, there are few punishments that are in place, as one individual is not held responsible. This has created an inefficient part of the system.

\section{Reforms \& Conclusions}

Discretion in sentencing, can reflect nature, context, and seriousness of the unlawful act which caused the death. Moreover by codifying the law, it would allow for clearer definitions for defendants to understand.

Furthermore, there must be reform on current legislation which have created Ineffective trials. However, some schools definitions allows for greater flexibility when dealing with such offences, this causes apprehension to change.
R v Adomako [1994] 3 WLR 288

The appellant was an anaesthetist, who, during an eye operation failed to notice the oxygen pipe had disconnected. Due to this the patient died. Adomako was convicted of the manslaughter of the patient by breach of duty.
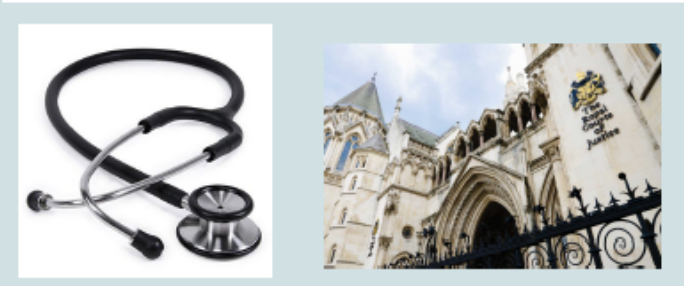

References

2007

159

159
Fenton [1830] 1 Lew CC 179
Franklin (1883) 15 Cox CC 163

$R$ v Furby (Andrew) [2005] EWCA Crim 3147 Larkin [1943] KB 174

Law Commission

Ashworth A, 'Manslaughter by Omission and the Rule of Law' [2015] Crim LR 563

Mitchell $B$, 'Minding the gap in unlawful and dangerous act manslaughter: a moral defence for one-punch killers' [2008] J. Crim. L.

Finch E and Fafinski S, 'Criminal Law' (6th edn,

Pearson, 2016)

d Storey T, 'Unlocking Criminal Law' (5th

edn, 2015)

Bar Council, 'When Clinical becomes Criminal:

Reforming Medical Manslaughter', (The Bar Council) Crown Prosecution Service 


\section{Should the laws on involuntary manslaughter in England and Wales be reformed?}

\section{Introduction}

The laws surrounding involuntary manslaughter construct a confused picture of accountability to possible defendants, with many areas to the spectrum of involuntary manslaughter being created within the law, different branches begin to face varying critiques. With issues ranging from high thresholds resulting in low successful prosecution rates, to lack of definitions within the law depriving the people of certainty and predictability. However, current laws offer unique benefits for the purpose of these crimes, moreover, the criminal justice system may even become damaged through unnecessary reforms.

\section{Constructive Manslaughter}

\section{Present Law}

The current law on constructive manslaughter lies with the simple definition of an unlawful, positive, criminal act, which caused the death and was dangerous. ${ }^{1}$ The requirement of an unlawful act has not always been in place, once being sufficient to only commit a civil wrong, as demonstrated in Fenton [1830]. ${ }^{2}$ However, this approach has changed and a criminal offence must be committed, 'The mere fact of a civil wrong committed by one person against another ought not to be used as an incident which is necessary step in a criminal case'. ${ }^{3}$ Furthermore, as it specifies a positive 'act', omissions cannot be used to find the defendant guilty. Finally, the dangerousness of the act must be 'an act which is likely to injure another person'. ${ }^{4}$ The mens rea of constructive manslaughter is explained in DPP $v$ Newbury and Jones (1977) and specifies that whilst it must be proved that the defendant intended to commit the unlawful act, there is no requirement that the defendant foresaw that his act may cause death or even harm.

\section{Issues found within present laws}

\footnotetext{
${ }^{1}$ Crown Prosecution Service, 'Homicide: Murder and Manslaughter- Legal Guidance, Violent crime' (The Crown Prosecution Service) $<$ www.cps.gov.uk/legal-guidance/homicide-murder-and-manslaughter $>$ accessed 14 November 2018

${ }^{2}$ Fenton [1830] 1 Lew CC 179

${ }^{3}$ Franklin (1883) 15 Cox CC 163

${ }^{4}$ Larkin [1943] KB 174
} 
The issues that constructive manslaughter presents to the modern law include the lack of set statute to offer definitions or legal principles. Having been developed haphazardly through common law, leading to uncertainty over what actually constitutes constructive manslaughter, and whether it should still be used for the full extent of crimes resulting in death, that it currently is. A topic area which exemplifies these issues is the matter of 'one-punch killers' - a current dispute within the area of constructive manslaughter which demonstrates the need for reform. Barry Mitchell argues in the Journal of Criminal Law 'the current law on UDA manslaughter is an example of constructive liability, and the case of the one punch killers graphically illustrates the common objection that the defendant lacks sufficient moral culpability for causing the victim's death; the gap between moral blame and death is simply too great'. ${ }^{5}$

\section{Reforms}

Whilst variations in the culpability of offences of constructive manslaughter is a controversial problem, it can be said that discretion in sentencing can be a way of resolving this issue. Sentencing can reflect the nature, context and seriousness of the unlawful act which caused the death, to create a fairer justice system that punishes defendants accordingly. However, troubles with sentencing for convictions of constructive manslaughter have been demonstrated in the case of Furby $2005{ }^{6}$ The case involved a man who struck a single blow to his friend $(V)$ on the cheek with moderate force, over altercations involving D's girlfriend, which resulted in V's death. D was sentenced to two and a half years' imprisonment. The case was appealed, and the court recognised the principle that 'the circumstances in which the punch was delivered would have a significant effect on the length of sentence, but where the consequences of the punch were not reasonably foreseeable, care must be taken to see that the effect was not disproportionate'. ${ }^{7}$ Lord Lane CJ decided by looking at the previous case of Coleman $1992,{ }^{8}$ that the starting point for the offence of manslaughter of this kind was 12 months' imprisonment on a plea of guilty, and D's sentence was substituted to 12 months' imprisonment on a plea of guilty.

Moreover, the Law Commission 2006 Murder, Manslaughter and Infanticide Report stated 'the over and under-inclusiveness of murder's current definition inevitably has the undesirable consequence of making it unduly difficult to devise a fair sentencing structurefor

\footnotetext{
${ }^{5}$ Barry Mitchell, 'Minding the gap in unlawful and dangerous act manslaughter: a moral defence for one-punch killers' [2008] J. Crim. L.

${ }^{6} R$ v Furby (Andrew) [2005] EWCA Crim 3147

${ }^{7}$ Ibid

${ }^{8} R$ v Coleman (Anthony Neville) (1992) 95 Cr. App R 159
} 
both murder and manslaughter. We believe that the introduction of a further tier to the general law of homicide will do great to resolve this problem'. ${ }^{9}$ Since Coleman was decided in 1992, 19 cases involving one punch deaths have been presented to the Court of Appeal. This statistic, along with the facts of the case of Furby, involving clear confusion and uncertainty of sentencing that involved costly and time-consuming intervention of the Court of Appeal to rectify, supports the Law Commission's suggestion that if the law on involuntary manslaughter became statute, then issues involving sentencing guidelines would be resolved, or at least less common.

\section{Gross negligence}

\section{Present Laws}

Gross negligence manslaughter specifies that "where death is a result of grossly negligent act or omission on the part of the defendant". ${ }^{10}$ In gross negligence manslaughter cases, the jury is directed to Lord Mackay's Speech in Adomako, which involved the duty owed by a hospital anaesthetist towards a patient. In the case of $R v$ Adomako, Lord Mackay outlines the direction in which the jury is to use in deciding the outcome of cases involving gross negligence manslaughter, the case developed the legal principle that 'The defendant's conduct must have 'departed from the proper standard of care incumbent upon him'. Where a person holds themselves out as possessing some special skill or knowledge, then their conduct will be judged against the reasonably competent professional in the field'. ${ }^{11}$ Due to the circumstances that surround Gross negligence laws, many medical law cases have been shaped through this common law.

\section{Issues found within present laws}

Collectively many of the journals and articles produced surrounding medical negligence states that there is a lack of a clear and precise definition of the law on gross negligence manslaughter. An article published by The Bar Council states that the law "fails to make the critical distinction between flagrant negligence and fleeting mistake". ${ }^{12}$ The issues that prevail is the uncertainty and inconsistency that is failing the justice system and sets a concerning unpredictable precedent for defendants, and as stated my Andrew Ashworth

\footnotetext{
${ }^{9}$ Law Commission,'Murder, Manslaughter and Infanticide' (Law Com No 304, p.27, 2006)

${ }^{10}$ Crown Prosecution Service, 'Homicide: Murder and Manslaughter- Legal Guidance, Violent crime' (The Crown Prosecution Service) $<$ www.cps.gov.uk/legal-guidance/homicide-murder-and-manslaughter> accessed 11 November 2018

${ }^{11}$ Emily Finch and Stefan Fafinski, 'Criminal Law' (6th edn, Pearson, 2016)

${ }^{12}$ Bar Council, 'When Clinical becomes Criminal: Reforming Medical Manslaughter', (The Bar Council) $<$ https://www.barcouncil.org.uk/media/627460/35 law reform essay.pdf> accessed 10 November 2018
} 
"People must be able to find out what the law is, and to factor it into their practical deliberations". ${ }^{13}$

In the same article produced by The Bar Council, it stated that the test set out in the case of Adomako "offers very little guidance as to what is meant by the elusive principle of 'grossness"'. The same issue arises in a report written by the Law Commission, which was outlining the faults of the current law on manslaughter, in the report it states that reckless indifference and gross negligence is currently defined as essentially the same crime, they suggest that there should be 'clear and robust differences between offences of different degrees of gravity". ${ }^{14}$

\section{Reforms}

The elusive nature of the term 'gross', is a common problem within the entire spectrum of law, and whilst academics may look for enlightenment from higher courts such as the Supreme Court, insight only extends to the disappointing circular answer, as demonstrated in $R v$ Adamako (1994) in which the Supreme Court (previously House of Lords) explained gross meant 'bad'. As suggested previously, this confusion could be reformed with a clear distinction of degrees of 'grossness'. If this was to be through statute it would avoid a controversial reversal on previous judgements through the courts. Whilst the Law Commission proposes a new offence of Killing by Gross Carelessness, which would require three forms of proof. 'The defendant's conduct involved an obvious risk of causing death or serious jury, of which he need not actually have been aware, as long as he was capable of appreciating it. Secondly, that his conduct fell far below what could be expected of him in all the circumstances, or that he intended to cause some unlawful injury to another or was reckless whether he did so. And, thirdly, that he caused death. ${ }^{, 15}$

\section{Reckless Manslaughter}

\section{Present Laws}

Reckless manslaughter can also be known as 'subjective manslaughter' whereby the accused has caused the victim's $(V)$ death and is aware that their actions involve a risk of causing death (or at least serious harm) and unreasonably takes that risk. ${ }^{16}$ Established to fill

\footnotetext{
${ }^{13}$ Andrew Ashworth, 'Manslaughter by Omission and the Rule of Law' [2015] Crim LR 563

${ }^{14}$ Law Commission, 'A new Homicide Act for England and Wales' (Law Com No 177, p.91, 2005)

${ }^{15}$ Law Commission, 'Legislating the Criminal Code, Involuntary Manslaughter', (Law Commission No.237, 1996)

${ }^{16}$ Ibid p.20-21
} 
the gap between unlawful dangerous act and gross negligence manslaughter, it's existence operates on an uncertain basis. A recent case is $R v$ Brown (2010) which demonstrates reckless manslaughter but also gross negligence manslaughter. The case was reckless manslaughter, as the defendant knew that her actions (or inaction) would worsen the victim's condition, however, she still took the risk, resulting in the victim's death.

\section{Issues found within present laws}

A main issue which reckless manslaughter presents is an ongoing academic debate over the term of 'reckless' used in modern law. The Law Commission has stated that although the word 'reckless' causes confusion in previous case law, they believe that, 'there is no other word equally suitable to serve as a label for 'unreasonably taking a risk of which the defendant is aware...' meaning that they do not want to change the offence by removing/adding a new word as it is simply a label. ${ }^{17}$ However, this label has condemned the legal practitioners to confusion. And whilst it allows for flexible within the common law, it removes the element of certain predictability within the law, a dangerous symptom of a failing law.

\section{Reforms}

There have been proposals for a new subsection to be added into reckless manslaughter to make it more clear. This recommendation is added onto the original two as aforementioned which is 'it is unreasonable for him or her to take that risk, having regard to the circumstances as he or she knows or believes them to be'. ${ }^{18}$ Furthermore, the Law Commission recommended that a defendant should only be held responsible to what they intended to cause and that the current law disproportionately punishes people who lack the intent, a view in opposition with an orthodox subjectivist theory. ${ }^{19}$

\section{Corporate}

\section{Present Laws}

Whilst the law separates involuntary manslaughter into three distinct areas, there is, in fact, an essential section which is often umbrellaed under many aspects of the three other sections, and this is corporate manslaughter. Corporate manslaughter is an offence that organisations can be held accountable for if how their activities are managed causes a person's death or result in a gross breach of a duty of care. This is how it is defined by

\footnotetext{
${ }^{17}$ Law Commission,'Involuntary Manslaughter' (Law Commission No.237, p.44, 1996)

${ }^{18}$ Ibid p.46

${ }^{19}$ Law Commission, 'Legislating the Criminal Code' (Law Commission No.218, 1993)
} 
Section 1 of the Corporate Manslaughter and Corporate Homicide Act 2007 which came into force on April 6th, 2008. ${ }^{20}$ It replaces previous common law and is much wider in the ground it covers. It now focuses on the offence of the whole management rather than on any individuals ,therefore, overcoming the 'identification principle'. ${ }^{21}$ This principle meant that a senior individual had to be guilty of gross negligence in order for the company to be guilty and this is no longer the case.

\section{Issues found within present laws}

It is firstly important to clarify the benefit that this new law covers, as it covers a much wider aspect of corporate manslaughter allowing for justice to be delivered in more cases. However, the downside of this Act is that it creates two laws, the corporation is prosecuted under the Act but managers or directors are still charged with the common law of gross negligence manslaughter which has a very high threshold. It can then create two separate trials which are ineffective. ${ }^{22}$ If the organisation is found guilty of this then there are few punishments that are in place, as it is not one person that is responsible, there are no custodial sentences. The most common penalty is that of a fine which can range from $£ 180,000$ to $£ 20$ million. $^{23}$ There is also a remedial order where it is required that the company take steps to fix the error that had resulted in death, along with this there is a publicity order meaning that the company has to publicise that it has been convicted of the offence which includes the details of the remedial order, the offence and the amount of fine given.

\section{Reform}

In terms of reform, one big area is lowering the threshold of being convicted of gross negligence to allow more prosecution to take place and to hold more senior figures to account for their mistakes.

\section{Conclusion}

In conclusion, many concerns around involuntary manslaughter are routed from the lack of clarity of law. These range from the common law not addressing the circular statements

\footnotetext{
${ }^{20}$ Corporate Manslaughter and Corporate Homicide Act 2007

${ }^{21}$ Crown Prosecution Service, 'Corporate Prosecutions' (The Crown Prosecution Service)

<https://www.cps.gov.uk/legal-guidance/corporate-prosecutions > Accessed 10 November 2018

22 Jacqueline Martin and Tony Storey, 'Unlocking Criminal Law' (5th edn, 2015)

${ }^{23}$ Crown Prosecution Service, 'Corporate Prosecutions' (The Crown Prosecution Service)

<https://www.cps.gov.uk/legal-guidance/corporate-prosecutions > Accessed 14 November 2018
} 
made within the courts over what is in fact 'gross'. Moreover, with the lack of statute, the flexibility of sentencing to the gravity of the offence is not proportionately represented. And finally, when it comes to corporate manslaughter, the thresholds are set to such a high standard, individuals are not receiving a fair and equal position before the courts, compared to large corporations. Whilst there are concerns over setting fundamental definitions of law, the current law has resulted in a failure of the justice system to provide a predictable legal system when it comes to involuntary manslaughter. 


\section{Bibliography}

Legislation

Corporate Manslaughter and Corporate Homicide Act 2007

\section{Cases}

$R v$ Coleman (Anthony Neville) (1992) 95 Cr. App R 159

Fenton [1830] 1 Lew CC 179

Franklin (1883) 15 Cox CC 163

$R$ v Furby (Andrew) [2005] EWCA Crim 3147

Larkin [1943] KB 174

\section{Law Commission Reports}

Law Commission, 'A new Homicide Act for England and Wales' (Law Com No 177, p.91, 2005)

Law Commission,'Involuntary Manslaughter' (Law Commission No.237, p.44, 1996)

Law Commission, 'Legislating the Criminal Code' (Law Commission No.218, 1993)

Law Commission, 'Legislating the Criminal Code, Involuntary Manslaughter', (Law Commission No.237, 1996)

Law Commission,'Murder, Manslaughter and Infanticide' (Law Com No 304, p.27, 2006)

\section{$\underline{\text { Journals }}$}

Ashworth A, 'Manslaughter by Omission and the Rule of Law' [2015] Crim LR 563

Mitchell B, 'Minding the gap in unlawful and dangerous act manslaughter: a moral defence for one-punch killers' [2008] J. Crim. L.

\section{$\underline{\text { Textbooks }}$}

Finch E and Fafinski S, 'Criminal Law' (6th edn, Pearson, 2016)

Martin J and Storey T, 'Unlocking Criminal Law' (5th edn, 2015)

\section{Online}

Bar Council, 'When Clinical becomes Criminal: Reforming Medical Manslaughter', (The Bar Council)

Crown Prosecution Service, 'Homicide: Murder and Manslaughter- Legal Guidance, Violent crime' (The Crown Prosecution Service)

Crown Prosecution Service, 'Corporate Prosecutions' (The Crown Prosecution Service) 